\title{
Artificial Spawning Behavior and Development of Eggs, Larvae and Juveniles of the Red Spotted Grouper, Epinephelus akaara in Korea
}

\author{
Jong Youn Park ${ }^{1}$, Jae Kwon Cho ${ }^{1}$, Maeng Hyun Son ${ }^{2}$, Kyong Min Kim ${ }^{2}$, \\ Kyeong Ho $\mathrm{Han}^{3}$, and ${ }^{\dagger} \mathrm{Jae} \mathrm{Min} \mathrm{Park}^{4}$ \\ ${ }^{I}$ Aquaculture Management Division, Aquaculture Research Institute, NIFS, Busan 46083, Korea \\ ${ }^{2}$ South Sea Fisheries Research Institute, NIFS, Yeosu 89780, Korea \\ ${ }^{3}$ Dept. of Aqualife Science, Chonnam National University, Yeosu 59626, Korea \\ ${ }^{4}$ Gyeongsangbuk-do Native Fish Business Center, Uiseong 37366, Korea
}

\begin{abstract}
This study was conducted in order to examine the egg development in red spotted grouper, Epinephelus akaara and the morphological development of its larvae and juveniles, and to obtain data for taxonomic research. This study was conducted in June 2013, and 50 male and female fish were used for the study. One hundred $\mu \mathrm{g} / \mathrm{kg}$ of LHRHa was injected into the body of the fish for inducing spawning, and the fish were kept in a small-sized fish holder $(2 \times 2 \times 2 \mathrm{~m})$. Eggs were colorless transparent free pelagic eggs, $0.71-0.77 \mathrm{~mm}$ large (mean $0.74 \pm 0.02 \mathrm{~mm}, \mathrm{n}=30$ ), and had an oil globule. Hatching started within $27 \mathrm{~h}$ after fertilization. Pre-larvae that emerged just after hatching were 2.02-2.17 mm in total length (mean $2.10 \pm 0.11$ $\mathrm{mm}$ ), their mouth and anus were not opened yet, and the whole body was covered with a membrane fin. Post-larvae that emerged 15 days post hatching were 3.88-4.07 mm in total length (mean $3.98 \pm 0.13 \mathrm{~mm}$ ), and had a ventral fin with two rays and a caudal fin with eight rays. Juveniles that were formed at $55 \mathrm{~d}$ post hatching, were $31.9-35.2 \mathrm{~mm}$ in total length (mean $33.6 \pm 2.33 \mathrm{~mm}$ ), with red color deposited over the entire body, and black chromophores deposited in a spotted pattern. The number of fin rays, body color, and shape were the same as that in the adult fish.
\end{abstract}

Key words : Epinephelus akaara, egg development, juvenile, larva

\section{INTRODUCTION}

Studies of early stages in the life cycle of fish are performed to obtain information such as morphological and physiological characteristics of eggs, as well as speciesspecific characteristics and developmental traits that can be observed during embryogenesis and early development. These studies provide taxonomical, developmental, and ecological knowledge, which can be used for the preservation of fish resources and for increasing their proliferation through seed production in different ways (Song \& Choi, 2000).

Epinephelus akaara is a fish that belongs to the Perciformes order and Serranidae family, with 12 genera and 27 species found in Korea. Epinephelus akaara is distributed in the south coast of Korea, Jeju-do, Japan, and China (Kim et al., 2005). The Serranidae are currently an economically important taxonomic group, with high industrial value, and several studies on the technical development of their stock

\footnotetext{
Manuscript received February 8, 2016, Received in revised form February 16, 2016, Accepted February 25, 2016

${ }_{\dagger}$ Corresponding Author: Jae Min Park, Gyeongsangbuk-do Native Fish Business Center, Uiseong 37366, Korea. Tel. : +82-54-830-8833, Fax : +82-54830-8809, E-mail : jm1090@korea.kr

This is an Open Access article distributed under the terms of the Creative Commons Attribution Non-Commercial License (http:// creativecommons.org/licenses/by-nc/3.0) which permits unrestricted non-commercial use, distribution, and reproduction in any medium, provided the original work is properly cited.
} 
production have been done (Heemstra \& Randall, 1993; Froese \& Pauly, 2014).

Domestic studies of the Serranidae include studies that have been performed on maturation and sex-reversal of the red spotted grouper, Epinephelus akaara (Lee et al., 1998); on the live food habits (Lee \& Hur, 1998), time of feeding (Lee \& Hur, 1997), changes of egg quality (Lee et al., 1997), and early life cycle of the sevenband grouper, Epinephelus septemfasciatus (Park et al., 2014). Besides these, studies on the skeletal (Park et al., 2015), and egg development; and the effects of water temperature and salinity (Yang et al., 2007; Cho et al., 2015) have also been conducted. Overseas studies include studies on egg development and on morphological development of larvae and juveniles of the sevenband grouper, Epinephelus septemfasciatus (Kitajima et al., 1991), that included studies on deformities in larvae and juveniles (Nagano et al., 2007), their spawning habits, and early life cycle (Ukawa \& Higuchi, 1966).

Studies on early life history are very useful for distinguishing between similar fish species, and for determining their relationships. A number of developmental traits provide significant data for elucidating taxonomic relationships (Blaxter, 1974; Balon, 1985). Epinephelus akaara is known to have a characteristic extension of rays in the dorsal and ventral fins at the early larval stage (Ukawa \& Higuchi, 1966; Song \& Noh, 1998). Although it is easily distinguished from larvae and juveniles of other marine fish, its morphology is similar to that of other Serranidae family larvae, which makes species identification of this taxonomic group difficult. Therefore, this study aims to provide information that might be useful for taxonomic research by investigating egg development, and the morphological development of larvae and juveniles of Epinephelus akaara.

\section{MATERIALS AND METHODS}

1. Breeding of adult fish and inducing spawning behavior
Fifty adult Epinephelus akaara fish (20 females and 30 males) were used in this study. They matured in June 2013 (37.9 $\pm 2.99 \mathrm{~cm}$ in total length and $888.7 \pm 244.7 \mathrm{~g}$ in weight). These fish were selected from 200 fish caught from the coast of Geomun-Island, Yeosu-si, Jeollanam-do using fish trap in September 2012 and grown in a fish holder $(7 \times 7 \times 5$ m). For the feed, combination of horse mackerel, squid, and oyster was provided twice a day at $1-2 \%$ of fish weight. To induce spawning behavior, $100 \mu \mathrm{g} / \mathrm{kg}$ of LHRHa was injected into the fish on the dorsal muscle of the lower side of the first ray and the fish were kept in a small-sized fish holder $(2 \times 2 \times 2 \mathrm{~m})$.

\section{Egg development}

Fertilized eggs were kept in a $1,000 \mathrm{~mL}$ glass beaker and the temperature of breeding water was maintained at $22.0-23.0^{\circ} \mathrm{C}$ (mean $22.5^{\circ} \mathrm{C}$ ) and salinity at $32.5-33.5 \%$ (mean 33.0\%) until hatching. Half the breeding water was replaced 5 times each day. Thirty eggs were retrieved randomly and their size was measured with a scale of 0.01 mm, using a phase-contrast microscope (Leica DE DM750, Germany). Egg development was monitored under a stereoscopic microscope (Nikon SMZ18, Japan) and photographs were also taken.

\section{Morphological development of larvae and juveniles}

Newly hatched larvae were kept in a circular water tank made of polypropylene (PP) and grown using the intensive pond system under mild ventilation with aeration and liquefied oxygen. As food supply for larvae, 5-10 Brachionus rotundiformis per $\mathrm{mL}$ were provided for 30 days after yolk absorption, and they were supplemented every $6 \mathrm{~h}$ to maintain the density. Combination of Brachionus rotundiformis and Artemia sp. were provided from day 30 to 50, and assorted feed (Lovelarva, Japan) was provided after day 50. For studying the morphological development of larvae and juveniles, 10 individuals were retrieved immediately post hatching and 
anesthetized using an anesthetic (MS-222, Ethyl 3-aminobenzoate methanesulfonate, Sigma Aldrich Co., St. Louis, USA), after which each region of the fish body was measured at the scale of $0.01 \mathrm{~mm}$ and observed under a stereoscopic microscope. Morphological developmental stages of larvae and juveniles were classified according to Kendall et al. (1984).

\section{RESULTS}

\section{Spawning behavior}

The spawning behavior of Epinephelus akaara was divided into 4 stages as shown in Fig. 1. During the spawning period, males showed nuptial coloration on their head in a spotted pattern, which became fainter towards the tail. Females had an inflated abdomen and the area around the gonopore was red and protruded. Males chased after females

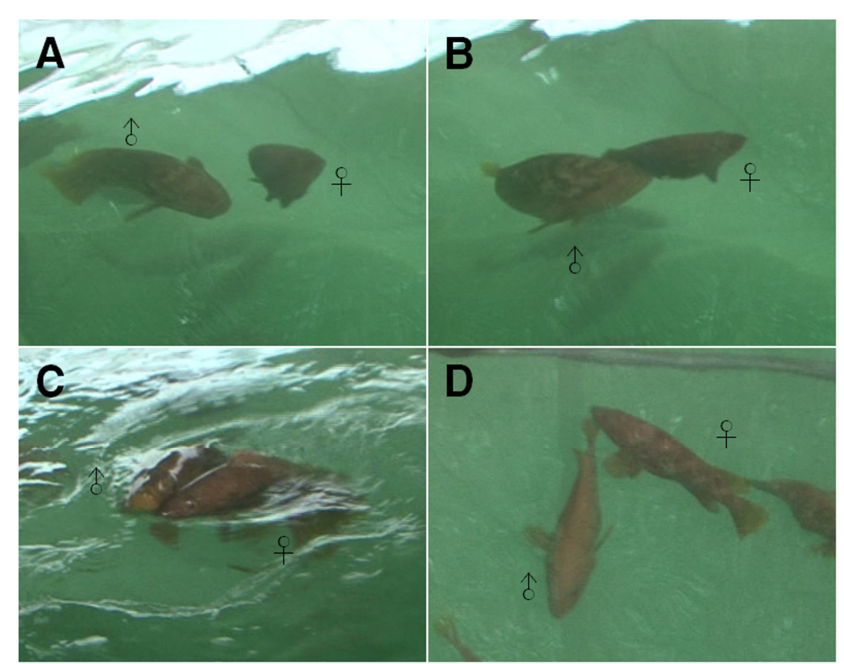

Fig. 1. The spawning behavior of the red spotted grouper, Epinephelus akaara. A: A male of nuptial coloration chasing after a female. B: The male stimulating the female's abdomen continuously using the head. $\mathrm{C}$ : The male and the female coming up to the surface of the water with their bodies touching each other, and spawning and ejaculation happening simultaneously. D: The male and female that had finished spawning fell apart and did spawning again repeatedly. consistently, and attacked any other males that approached them (Fig. 1A). Males stimulated females' abdomen using their head and pushed the females to the surface of the water (Fig. 2B). Males and females moved up to the surface of the water with their bodies attached and swam in circles, while spawning and ejaculation occurred simultaneously (Fig. 1C). After spawning, males and females were separated and initiated spawning again (Fig. 1D).

\section{Egg development}

The eggs were $0.71-0.77 \mathrm{~mm}$ in size (mean $0.74 \pm 0.02 \mathrm{~mm}$, $\mathrm{n}=30$ ), had one oil globule, and were colorless, transparent, and free pelagic eggs. Fertilized eggs were transferred to the lab immediately after spawning and were observed starting from the $12 \mathrm{~h}$ time point post fertilization. We found that at the stage of the embryonic period, the head was formed and a Kupffer's vesicle had also formed at the end of the tail (Fig. 2A). Kupffer's vesicle disappeared at $20 \mathrm{~h}$ post-fertilization and the embryo began to move; eyes were formed on the head and a primordial fin was present

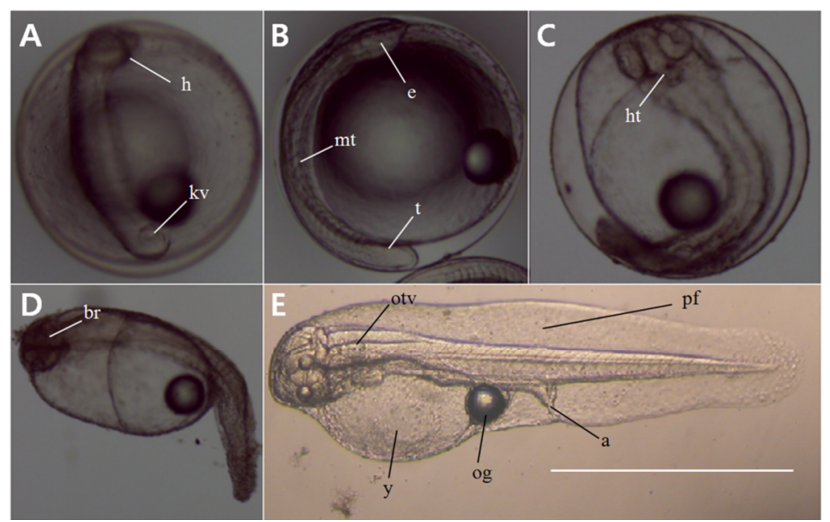

Fig. 2. Egg development of red spotted grouper, Epinephelus akaara. A: Embryo and Kupffer's vesicle formation, $12 \mathrm{~h}$; B: Primordial fin of developing, 20 h; C: Heart beating, 25 h; D-E: Hatching larva, $27 \mathrm{~h}$. Scale bar $=1.0 \mathrm{~mm}$. a-anus; br-brain; e-eye; h-head; ht-heart; kv-Kupffer's vesicle; mt-myotomes; og-oil globule; otv-otic vesicle; pf-primordial fin; $\mathrm{t}$-tail; $\mathrm{y}$-yolk. 
on the tail (Fig. 2B). At the time point $25 \mathrm{~h}$ post-fertilization, the embryo started moving actively, the heart had formed, and the heart beat at this stage with the rate of 65 72 beats per min (Fig. 2C). Hatching began at $27 \mathrm{~h}$ postfertilization, as the embryo broke out of the egg membrane with its tail first (Fig. 2D-E).

\section{Morphological development of larvae and juveniles}

Newly hatched pre-larvae were $2.02-2.17 \mathrm{~mm}$ in size (mean $2.10 \pm 0.11 \mathrm{~mm}$ ) with their mouth and anus not opened yet, and the whole body covered with a membrane fin. The newly hatched pre-larvae had a yolk and one oil globule, did not have the ability to swim and adhered to the bottom or the wall. The digestive tract within the body had developed as a straight line, and the number of myotomes was 23-25 (Fig. 3A).

Pre-larvae at 2 days post hatching were $2.21-2.30 \mathrm{~mm}$ in total length (mean $2.26 \pm 0.06 \mathrm{~mm}$ ), and the membranous fin was divided from the anus. The sizes of the yolk and the oil globule had reduced. A caudal fin had adopted the shape of a fan, and was actively moving (Fig. 3B).

At 4 days post hatching, the pre-larvae reached 2.43$2.54 \mathrm{~mm}$ in length (mean $2.49 \pm 0.08 \mathrm{~mm}$ ) and entered postlarval stage with the entire yolk being absorbed. The mouth and anus were opened, and only a trace of the oil globule remained. The membrane fin that was covering the entire body got connected from the upper head to the lower abdomen, and a round pectoral fin was formed. The digestive tract which had been in a straight line changed into a helical form, and branch-shaped black chromophores were deposited at the top. Pigments were deposited on the lens in the center of the eyes. The number of myotomes increased to 26-28 (Fig. 3C).

Post-larvae at 9 days post hatching were $3.30-3.58 \mathrm{~mm}$ in length (mean $3.44 \pm 0.20 \mathrm{~mm}$ ) and 6 rays were formed on the round pectoral fin, while 1 ray was formed on the dorsal fin. Branch-shaped black chromophores, which were
A

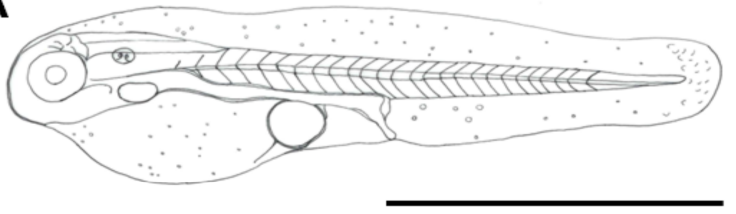

B
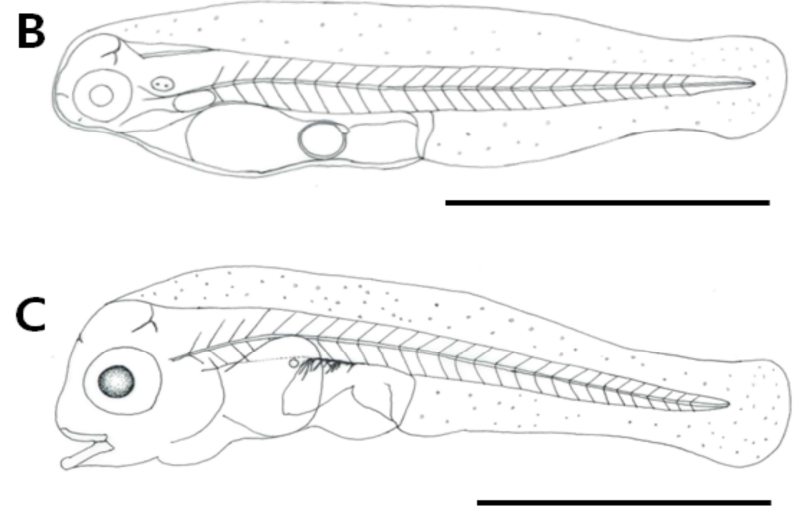

D

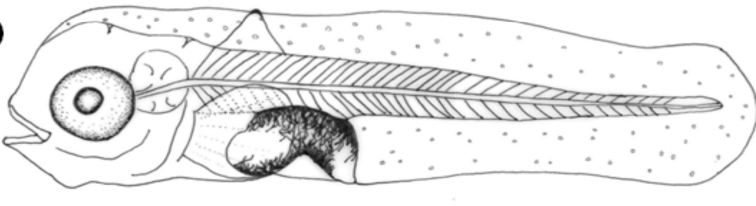

Fig. 3. Larval development of the red spotted grouper, Epinephelus akaara. A: Newly hatched pre-larvae were $2.10 \mathrm{~mm}$ in size with their mouth and anus not opened yet. B: Pre-larvae at 2 days after hatching were $2.26 \mathrm{~mm}$ in size and their anus opened. $\mathrm{C}$ : Pre-larvae at 4 days after hatching were 2.49 $\mathrm{mm}$ in size and their mouth opened, a round pectoral fin was formed. D: Post-larvae at 9 days post hatching were $3.44 \mathrm{~mm}$ in size and 1 ray was formed on the dorsal fin.

previously deposited only above the digestive tract, got distributed more widely on the body, and could be seen below the abdomen also. Pigments were deposited all over the eyes including the center. The anus constituted $37.4 \%$ of the body length, reaching almost the center of the body (Fig. 3D).

Post-larvae at 15 days after hatching were $3.88-4.07$ $\mathrm{mm}$ in length (mean $3.98 \pm 0.13 \mathrm{~mm}$ ), and 1 ray that had formed on the dorsal fin was extended. Two rays were 
formed on the ventral fin and 8 rays on the caudal fin. The membrane fin was connected from the dorsal fin ray to the anus. Black chromophores were deposited on the caudal peduncle and also at the end of the dorsal and ventral fin rays in a spotted pattern (Fig. 4A).

Post-larvae at 25 days post hatching were $4.11-6.32 \mathrm{~mm}$ in length (mean $5.22 \pm 1.56 \mathrm{~mm}$ ) and 2 bones were formed on the operculum. The membrane fin was divided into dorsal, ventral, anal, and caudal fins. Black chromophores were deposited on the front mouth, upper head, and the center of the caudal peduncle. The number of fin rays was increased to 25 in the dorsal fin, 12 in the pectoral fin, and 14 in the caudal fin, and 10 rays were formed on the anal fin (Fig. 4B).

Post-larvae at 34 days after hatching were 12.6-17.1 $\mathrm{mm}$ in length (mean $14.9 \pm 3.18 \mathrm{~mm}$ ) and the bones formed on the operculum were increased to three. One ray on the second dorsal fin and 2 rays on the first ventral fin were extended, and both ends resembled the shape of a sawtooth. Black chromophores were widely deposited on the head and also on the operculum in a spotted pattern. The number of rays in each fin increased to 26 in the dorsal fin, 12 in the anal fin, and 4 in the ventral fin. At this stage, the position of the anus was at $47.8 \%$ of the body length, proximal to the center of the body (Fig. 4C).

Post-larvae at $46 \mathrm{~d}$ after hatching were $19.2-22.5 \mathrm{~mm}$ in length (mean $20.9 \pm 2.3 \mathrm{~mm}$ ) and the extended rays of the second dorsal fin and the first ventral fin were reduced in length. Black chromophores were deposited on the center of the body and on the back in a spotted pattern. The number of rays in each fin had increased to 28 in the dorsal fin, 6 in the ventral fin, 17 in the pectoral fin, and 18 in the caudal fin. At this stage, the position of the anus was at $50.0 \%$ of the body length, thereby right at the center of the body (Fig. 4D).

Post-larvae at $55 \mathrm{~d}$ after hatching were $31.9-35.2 \mathrm{~mm}$ in total length (mean $33.6 \pm 2.33 \mathrm{~mm}$ ). Red color was deposited

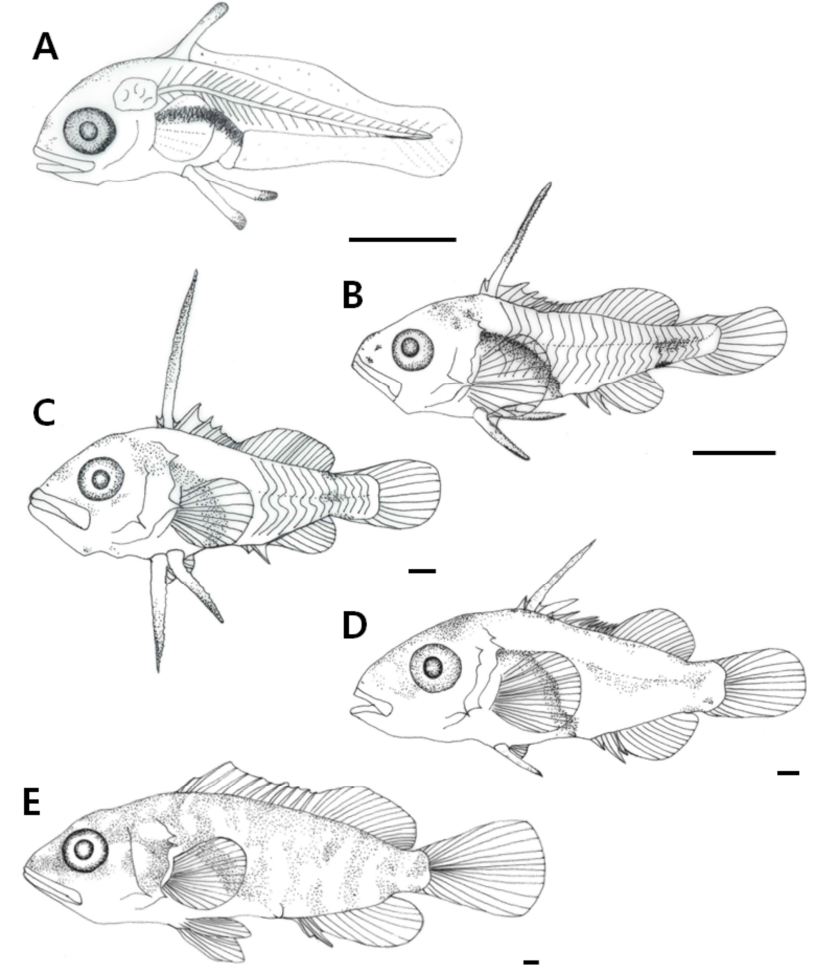

Fig. 4. Development of larvae and juveniles of the red spotted grouper, Epinephelus akaara. A: Postlarvae at 15 days after hatching were $3.98 \mathrm{~mm}$ in size and two rays were formed on the ventral fin. B: Post-larvae at 25 days after hatching were $5.22 \mathrm{~mm}$ in size and one ray on the second dorsal fin were extended. C: Post-larvae at 34 days after hatching were $14.9 \mathrm{~mm}$ in size and the each part of membranous fin was divided. D: Post-larvae at 46 days after hatching were $20.9 \mathrm{~mm}$ in size. rays of the second dorsal fin were extended and the first ventral fin were reduced in length. E: Post-larvae at 55 days after hatching were $33.6 \mathrm{~mm}$ in size and their fin rays, body color and morphology was similar to that in the adult fish.

on the entire body and black chromophores were deposited in a spotted pattern. As the number of rays in the ventral fin increased to 8 , the number of fin rays, body color, and morphology was similar to that in the adult fish, which led to the juvenile stage. At this stage, the position of the anus was at $49.4 \%$ of the body length, proximal to the center of 
the body (Fig. 4E).

\section{DISCUSSION}

Fertilized eggs of Epinephelus akaara are globular-shaped, colorless, and transparent free pelagic eggs with one oil globule. Other marine fish that have free pelagic eggs include Paralichthys olivaceus (Han \& Kim, 1997), E. bruneus (Lee \& Go, 2003), E. septemfasciatus (Park et al., 2014), Oplegnathus punctatus (Park et al., 2015), O. fasciatus (Koh \& Kim, 1992), Acanthopagrus schlegelii (Kim, 1970) and Scomber japonicus (Park et al., 2008), all of which have eggs with one oil globule. Although fertilized eggs with such characteristics are difficult to classify morphologically, differences were observed in the egg sizes, the number of oil globules, as well as in the presence or absence of black chromophores.

The egg size of Epinephelus akaara was $0.71-0.77 \mathrm{~mm}$ (mean $0.74 \pm 0.02 \mathrm{~mm}$ ), which was similar to $0.70-0.77 \mathrm{~mm}$ reported by Ukawa \& Higuchi (1966) and slightly different from the $0.71-0.82 \mathrm{~mm}$ size reported by Song \& Noh (1998). The egg sizes can differ depending on maturity level, therefore comparative studies on the hatching rate, and egg and larval sizes that take into consideration the maturity level of the fish are further required. The egg size of Epinephelus akaara is smaller than the observed egg sizes for E. septemfasciatus (mean $0.85 \mathrm{~mm}$ ) (Park et al., 2014), E. bruneus (mean $0.90 \mathrm{~mm}$ ) (Lee \& Go, 2003), Nassau grouper, E. striatus (mean $0.92 \mathrm{~mm}$ ) (Allyn et al., 1992), and for the Humpback grouper, Cromileptes altivelis (mean $0.83 \mathrm{~mm}$ ) (Bulanin et al., 2005), all of which belong to the same family. This shows that other fish of the Serranidae family display differences in their egg sizes, that enables differentiation between these fish.

Water temperature is an environmental factor that affects the development of larvae and juveniles, determines the hatching time for fertilized eggs, and directly affects organogenesis from the embryological aspect (Hempel, 1979; Byun et al., 2007). The time required for hatching in Epinephelus akaara varied with water temperature; it was $27 \mathrm{~h}$ at the mean water temperature of $22.5^{\circ} \mathrm{C}$ in the present study, $23-25 \mathrm{~h}$ at $25.1-27.0^{\circ} \mathrm{C}$ as reported in Ukawa \& Higuchi (1966), and $25.5 \mathrm{~h}$ at the mean water temperature of $25.0^{\circ} \mathrm{C}$ from Song \& Noh (1998). Moreover, the hatching time is $48 \mathrm{~h}$ for E. septemfasciatus (Park et al., 2014) at water temperature of $21.5-23.5^{\circ} \mathrm{C}$ (mean $\left.22.0^{\circ} \mathrm{C}\right), 32 \mathrm{~h}$ for E. bruneus (Lee \& Go, 2003) at mean water temperature of $25.0^{\circ} \mathrm{C}, 20 \mathrm{~h}$ and $10 \mathrm{~min}$ for Humpback grouper (Bulanin et al., 2005) at water temperature of $27.0-28.0^{\circ} \mathrm{C}$, and $27-$ $29 \mathrm{~h}$ for Nassua grouper (Allyn et al., 1992) at water temperature of $23.0-30.0^{\circ} \mathrm{C}$, showing differences between species. Fish of the Serranidae family showed a tendency of decreasing hatching time at higher water temperature. Differences in time at similar water temperature are most likely a characteristic of the species, but most showed a close relationship with water temperature. Such tendency is also observed in various kinds of fish including Girella punctate and G. melanichthys (Oh et al., 2010), halibut (Kim et al., 2010), Gadus macrocephalus (Lee et al., 2007), mackerel (Hwang et al., 2008), Takifugu pardalis (Han \& Cho, 2007), and Microstomus achne (Byun et al., 2009).

We found the larval size of Epinephelus akaara to be 2.02-2.17 $\mathrm{mm}$ in length (mean $2.10 \pm 0.11 \mathrm{~mm}$ ), while Ukawa \& Higuchi (1966) reported it to be 1.45-1.56 $\mathrm{mm}$ and Song \& Noh (1998) reported a mean of $1.65 \mathrm{~mm}$, showing that there are differences between the studies. Total length of larvae was found to be $1.74 \mathrm{~mm}$ (mean) in E. septemfasciatus, $1.30-1.40 \mathrm{~mm}$ in E. fasciatus (Kawabe et al., 2009), $1.86 \mathrm{~mm}$ (mean) in Humpback grouper (Bulanin et al., 2005), and 1.70-1.80 $\mathrm{mm}$ in Nassau grouper (Allyn et al., 1992), which were all shorter than the length of Epinephelus akaara larvae. Length of E. bruneus larvae was $2.02 \mathrm{~mm}$ (Lee \& Go, 2003), which was in a similar range.

Fish of the Serranidae family undergo morphological 
changes at the post-larval stage. The onset of these changes depends on the time when the second ray of the dorsal fin and the first ray of the ventral fin begin to extend. In the present study, the onset of morphological changes in Epinephelus akaara was observed to be on the 15th day after hatching, and when the length was $3.98 \mathrm{~mm}$. Similar results were reported by Ukawa \& Higuchi (1966), where the onset of morphological changes were observed 15 days after hatching and when the length was $4.05 \mathrm{~mm}$ and by Song \& Noh (1998) who reported it to occur between 1417 days after hatching. Although there were differences in total length, the timing was similar. Morphological changes of E. septemfasciatus (Park et al., 2014) occurred at 8 days after hatching, which was earlier than that of Epinephelus akaara. The onset of morphological changes, and larval size are likely to differ depending on feeding, breeding conditions, and development.
The number of days taken to reach the juvenile stage was 55 days post hatching and the size of the juveniles was $31.9-35.2$ in total length (mean $33.6 \pm 2.33 \mathrm{~mm}$ ) in Epinephelus akaara. It was $61 \mathrm{~d}$ post hatching and the mean length was $32.9 \mathrm{~mm}$ for E. septemfasciatus (Park et al., 2014). Thus, their sizes were similar but Epinephelus akaara needed a shorter time for attaining the juvenile stage. E. bruneus (Lee \& Go, 2003) attained the juvenile stage $50 \mathrm{~d}$ after hatching and reached $10.5 \mathrm{~mm}$ in total length; E. fasciatus (Kawabe et al., 2009) required $30 \mathrm{~d}$ post hatching and attained a length of $12.4 \mathrm{~mm}$; Nassau grouper (Allyn et al., 1992) required $40 \mathrm{~d}$ after hatching and attained a mean length of $13.5 \mathrm{~mm}$. Compared to these fish, Epinephelus akaara took longer time and had a bigger size (Table 1).

Several studies have been performed on the technical development of the domestic Serranidae stock production in Korea. However, not many studies have been performed

Table 1. Comparison between developmental and morphological characteristics of eggs, larvae, and juveniles from fish belonging to the serranidae family

\begin{tabular}{|c|c|c|c|c|c|}
\hline Species & $\begin{array}{l}\text { Egg diameter } \\
\qquad(\mathrm{mm}, \\
\text { mean } \pm \mathrm{SD})\end{array}$ & $\begin{array}{l}\text { Time of hatching } \\
(* \text { WT })\end{array}$ & $\begin{array}{l}\text { Size of the hatching } \\
\text { larvae }(\mathrm{mm}, \\
\text { mean } \pm \text { SD) }\end{array}$ & $\begin{array}{c}\text { Size of the } \\
\text { juveniles } \\
(\mathrm{mm}, \text { mean } \pm \mathrm{SD})\end{array}$ & References \\
\hline Epinephelus akaara & $\begin{array}{c}0.74 \pm 0.02 \\
(0.71-0.77)\end{array}$ & $\begin{array}{c}27 \mathrm{~h} \\
\left(22.5^{\circ} \mathrm{C}\right)\end{array}$ & $\begin{array}{c}2.10 \pm 0.11 \\
(2.02-2.17)\end{array}$ & $\begin{array}{c}33.6 \pm 2.33 \\
(31.9-35.2)\end{array}$ & Present study \\
\hline Epinephelus akaara & $0.70-0.77$ & $\begin{array}{c}23-25 \mathrm{~h} \\
\left(25.1-27.0^{\circ} \mathrm{C}\right)\end{array}$ & $1.45-1.56$ & - & $\begin{array}{c}\text { Ukawa \& } \\
\text { Higuchi, } 1966\end{array}$ \\
\hline Epinephelus akaara & $0.71-0.82$ & $\begin{array}{c}25 \mathrm{~h} 30 \mathrm{~min} \\
\left(25.0^{\circ} \mathrm{C}\right)\end{array}$ & 1.65 & - & $\begin{array}{c}\text { Song \& Noh, } \\
1998\end{array}$ \\
\hline Epinephelus septemfasciatus & 0.85 & $\begin{array}{c}48 \mathrm{~h} \\
\left(21.5-23.5^{\circ} \mathrm{C}\right)\end{array}$ & 1.74 & 32.9 & Park et al., 2014 \\
\hline Epinephelus bruneus & 0.90 & $\begin{array}{c}32 \mathrm{~h} \\
\left(25.0^{\circ} \mathrm{C}\right)\end{array}$ & 2.02 & 10.5 & Lee \& Go, 2003 \\
\hline Epinephelus striatus & 0.92 & $\begin{array}{c}27-29 \mathrm{~h} \\
\left(23.0-30.0^{\circ} \mathrm{C}\right)\end{array}$ & 1.86 & 13.5 & Allyn et al., 1992 \\
\hline Epinephelus fasciatus & - & - & $1.30-1.40$ & 12.4 & $\begin{array}{l}\text { Kawabe et al., } \\
2009\end{array}$ \\
\hline Cromileptes altivelis & 0.83 & $\begin{array}{c}20 \mathrm{~h} 10 \mathrm{~min} \\
\left(27.0-28.0^{\circ} \mathrm{C}\right)\end{array}$ & $1.70-1.80$ & - & $\begin{array}{l}\text { Bulanin et al., } \\
2005\end{array}$ \\
\hline
\end{tabular}

${ }^{*}$ WT: water temperature. 
on egg development and morphological development of larvae and juveniles. Further studies on the early stages of the life cycle of the Serranidae family are required to promote the taxonomical research on larvae and juveniles, and to elucidate the causes of characteristics such as deformities, large-scale mortality, and cannibalism that occur during breeding.

\section{ACKNOWLEDGEMENT}

This research was supported by the project of National Institute of Fisheries Science (NIFS), Republic of Korea (R2016021).

\section{REFERENCES}

Allyn B, Powell JW, Tucker JR (1992) Egg and larval development of laboratory. Reared nassau grouper, Epinephelus striatus (Pisces, Serranidae) Bull Marine Sci 50:171-185.

Balon EK (1985) Early Life Histories of Fishes: New Developmental, Ecological and Evolutionary Perspectives. dr. W. Junk Publisher, Dordrecht 280pp.

Blaxter JHS (1974) The Early Life History of Fish. SpringVerlag Berlin, Heidelberg 765pp.

Bulanin U, Saad CR, Kamarudin MS, Affandi R, Sudaryono A (2005) Eggs and prelarvae development for humpback grouper, Cromileptes altivelis (Valencee) larvae. Aqua Indonesia 6:115-121.

Byun SG, Lee BI, Lee JH, Ku HD, Park SU, Yun SM, Hwang SY, Kim YC, Han HG (2007) Egg development and morphological change of larvae and juveniles of the starry flounder, Platichthys stellatus. Korean J Ichthyol 19:350-359. (in Korean)

Byun SG, Lee SH, Hwang JH, Han KH, Yeon IH, Kim JD, Lee JH, Lee BI (2009) Effect of water temperature on the embryonic development of slime flounder Microstomus achne. Dev Reprod 13:265-270. (in Korean)
Cho JK, Hong CG, Park JY, Son MH, Park CK, Park JM (2015) Effects of water temperature and salinity on the egg development and larvae of sevenband grouper, Epinephelus septemfasciatus. Korean J Ichthyol 27:21-25. (in Korean)

Froese R, Pauly D (2014) FishBase. World wide web electronic publication. www.fishbase.org (version 02/2014).

Han KH, Cho JK (2007) Effect of water temperature on the embryonic development of pather puffer, Takifugu pardalis. J of Aquacult 20:265-269. (in Korean)

Han KH, Kim YU (1997) The early life history of the flounder, Paralichthys olivaceus. Development of egg, larvae and juveniles. Bull Yosu Nat Fish Univ 11:105117. (in Korean)

Han KH, Kim YU (1999) Eggs development and morphology of larvae of the flounder Limanda herzensteini. Korean J Ichthyol 11:86-93. (in Korean)

Heemstra PC, Randall JE (1993) FAO species catalogue. Vol. 16. Groupers of the world (family Serranidae, subfamily Epinephelinae). An annotated and illustrated catalogue of the grouper, rockcod, hind, coral grouper and lyretail species known to date. FAO Fishieries Synopsis 125:382.

Hempel G (1979) Early Life History of Marine Fish. Univ. Washington Press, pp. 38-60.

Hwang HK, Kim DH, Park MW, Yoon SJ, Lee YH (2008) Effects of water temperature and salinity on the egg and larval of chub mackerel Scomber japonicus. J of Aquacult 21:234-238. (in Korean)

Kawabe K, Kohno H (2009) Morphological development of larval and juvenile blacktip grouper, Epinephelus fasciatus. Fish Sci 75:1239-1251.

Kendall AW Jr, Ahlstrom EH, Moser HG (1984) Early life history stages of fishes and their characters. In: Moser, H.G. et al. (eds.), Ontogeny and Systematics of Fishes. Am Soc Ichthyol Herpetol Spec Publ 1:11-22, Allen Press, Lawrence, KS. 
Kim IS, Choi Y, Lee CL, Lee YJ, Kim BJ, Kim JH (2005) Illustrated Book of Korean Fishes. Kyo-Hak Publishing Co Ltd. Seoul. pp. 276-286. (in Korean)

Kim YS, Do YH, Kim SY, Chang YJ (2010) Developmental speed of olive flounder Paralichthys olivaceus eggs in various water temperature. Dev Reprod 14:59-63. (in Korean)

Kim YU (1970) On the characteristics of eggs and larva of Mylio macrocephalus (Basilewsky). Bull Korean Fish Soc 3:233-250. (in Korean)

Kitajima C, Takaya M, Tsukashima Y, Arakawa T (1991) Development of eggs, larvae and juvenile of the grouper, Epinephelus septemfasciatus, reared in the laboratory. Japan J Ichthyol 38:47-55.

Koh JL, Kim YU (1992) Embryonic development and morphology of larvae and juveniles of parrot Fish, Oplegnathus fasciatus (Temminck et Schlegel). PhD thesis, Pukyong Nat Univ 32:29-45. (in Korean)

Lee CK, Hur SB (1997) Yolk resorption, onset of feeding and survival potential of larvae of red spotted grouper, Epinephelus akaara. J of Aquacult 10:473-483. (in Korean)

Lee CK, Hur SB (1998) Effect of live food and water temperature on larval survival of red spotted grouper, Epinephelus akaara. J of Aquacult 11:565-572. (in Korean)

Lee CK, Hur SB, Ko TS, Park S (1998) Maturation, sex ratio and sex-reversal of red spotted grouper, Epinephelus akaara. J of Aquacult 11:573-580. (in Korean)

Lee CK, Hur SB, Park S, Kim BG (1997) Qualities of spawned eggs during the spawning period in red spotted grouper, Epinephelus akaara. J of Aquacult 10:463-472. (in Korean)

Lee JY, Lee CS, Kim WK, Park SU, Min BH (2007) Effects of water temperature on egg development, hatching and larval growth rearing of the pacific cod Gadus macrocephalus. J of Aquacult 20:260-264. (in Korean)

Lee YD, Go KM (2003) Aquatic industrialization by development of reproductive technology of sevenband grouper, Epinephelus septemfasciatus. Jeju Univ pp.1-86. (in Korean)
Nagano N, Hozawa A, Fujiki W, Yamada T, Miyaki K, Sakakura Y, Hagiwara A (2007) Skeleton development and deformities in cultured larval and juvenile sevenband grouper, Epinephelus septemfasciatus (Thunberg). Aqua Res 38:121-130.

Oh BS, Choi YU, Ku HD, Kim SC, Jung MM, Park HS (2010) The effect of water temperature on egg development stages of largescale blackfish Girella punctata and smallscale blackfish Girella melanichthys. Dev Reprod 14:51-58. (in Korean)

Park CK, Yeon IH, Choi NH, Heo SJ, Han KH, Lee WK (2008) Egg development and morphology of larva and juvenile of the chub mackerel, Scomber japonicus. Dev Reprod 12:207-213. (in Korean)

Park JM, Cho JK, Han KH, Kim NR, Hwang HK, Kim KM, Myeong JI, Son MH (2014) Early life history of the sevenband grouper, Epinephelus septemfasciatus from Korea. Dev Reprod 18:13-23. (in Korean)

Park JM, Lee SH, Lee SM, Na HC, Han KH (2015) Egg development and morphology of larvae and juveniles of spotted knifejaw, Oplegnathus punctatus. Korean J Ichthyol 27:71-77. (in Korean)

Park JY, Hong CG, Cho JK, Son MH, Han KH, Park JM (2015) Early osteological development of the larvae and juveniles in sevenband grouper, Epinephelus septemfasciatus (Pisces: Serranidae). Korean J Ichthyol 27:189198. (in Korean)

Song CB, Noh S (1998) Study on seed production of the red grouper, Epinephelus akaara, and its feed organism. Jeju Univ pp. 23-97. (in Korean)

Song HB, Choi SS (2000) Reproductive ecology and early life history of paradise fish, Macropodus chinensis (Pisces: Belontidae) in aquarium. Korean J Limnol 33: 282-294. (in Korean)

Ukawa M, Higuchi M (1966) Spawning habits and early life history of a serranid fish, Epinephelus akaara. Japan J Ichthyol 13:156-161. 
JY Park, JK Cho, MH Son, KM Kim, KH Han, JM Park

Yang MH, Choi YU, Jung MM, Ku HD, Oh BS, Moon TS, Lee CH, Kim KM, Han SJ (2007) Temperature effect in egg development and hatching of longtooth grouper, Epinephelus bruneus. Dev Reprod 11:105-109. (in Korean) 